\title{
Analysis of Childhood Social Development to Single Parents
}

\author{
Paradita Kumala Lemmy \\ College Student in Postgraduate \\ State University Medan \\ Medan, Indonesia \\ paraditakumalalemmy@gmail.com
}

\author{
Anita Yus \\ Lecture of Postgraduate \\ State University of Medan \\ Medan, Indonesia
}

\author{
Asmin \\ Lecture of Postgraduate \\ State University of Medan \\ Medan, Indonesia
}

\begin{abstract}
The purpose of this study is to find out whether there is a significant relationship between: (1) achievement of social development in childhood who have single parents, (2) how is the social behavior of children who have single parents, (3) how childrens social behavior who is cared for by a single mother, (4) how is the social behavior of a child cared for by a single father. This study was an analytic observational study with a cross sectional design. The population of this study was all early childhood education in 3 kindergarten schools in Medan City. The research method used in this study is a qualitative analytical descriptive method. The sampling technique used is Area sampling. Data collection techniques for social development using questionnaires, interviews, documentation and observation. The data analysis technique uses 3 techniques, namely data reduction, data presentation and conclusion drawing. Based on the results of the data analysis and the discussion carried out obtained: (1) There is a difference between the social development of children with single parents and complete parents where children with single parents tend to have unstable emotions. They are easier to cry when disturbed by their friends for those who are cared for by a single mother, for those who are cared for by a single father, they tend to be angry, rebellious and hit when they are disturbed by their friends; (2) engagement parenting conducted in independent and not involved to the other; (3) accessibility is a single parent, father always give time to accompany for playing and activities his child everyday.
\end{abstract}

Keywords: Social Development, Chilhood, Single Parent.

\section{INTRODUCTION}

The family is the smallest group in the environment where humans carry out activities in everyday life. Generally a family consists of father, mother and child. For family life, father and mother have the role of parents of children. Father and mother are people who are needed by children in their lives. Parents have duties and responsibilities carried out each in accordance with their functions. So as a single parent (single parents) of course someone has a tougher task, especially in parenting and communication with their children. Single parents is a phenomenon that generates new views in a family structure. The more widespread the phenomenon of being a single parent, the more descriptions of the definition of single parents themselves. Single parents are someone who performs the task as a parent (father or mother) alone, because of loss or separation from their partners [1].
Based on the survey and observation that I did in PAUD Al-Bahri, it was recorded that 4 students were raised by a single parent with a total of 30 students, at ABA Aisyiyyah Kindergarten 3 students with a total of 30 students and TK ArRidho Medan with 2 students 30 people. Some cases of single parents in these schools came from divorce, which reached $75 \%$ and another $25 \%$ because one of the students' parents died. Divorce itself is most desired by the wife. The main problem for single parents, especially for women, is the economic problem because women will not only take care of the house and children but also think how to provide for their lives and children. For men more likely to have difficulty becoming a mother with activities that work outside and take care of children or take care of work at home, who are not accustomed to doing housework. Imbalance that occurs in the family will greatly affect the child. Single parents or single parents in the family become a big problem for children, especially in parenting that is good for social and emotional development.

Social emotions are psychological aspects that are very influential in children. Where the environmental conditions affect the child's psychological development. Like a very busy life environment, bad impact on children's social emotions, that is, children are more easily upset and angry in dealing with all things. Mahyar [2] said in his research "Social development of children is very dependent on the individual child, the role of parents, the community environment and including kindergarten. There is a close relationship between social skills and happy times in childhood. The ability of children to adjust to the environment. Acceptance of the environment and other positive experiences during social activities is a basic capital that is very important for a successful and enjoyable life in the future. According to Tri [3] in his study said that children who have a family of single parents or single parents who are 3-4 years old are experiencing attentional and shy behavior. This is due to the lack of attention and affection given by his parents who are single parents.

Astuti [4] in her study stated that the children of single parents aged 5-6 years in their emotional social development develop more positively than developing in the negative direction. The study was conducted where children who have single parent parents carry out activities related to social emotions positively by working together at school, helping 
friends, various foods, being patient with friends and being able to take part in competitions held at school. Only a few negative behaviors are not confident so afraid to try something new, quarreling, not wanting to carry out the teacher's orders, acting spoiled with those closest to you, at rest preferring to see his friend playing .

Emotional control of early childhood can be seen from the association in school by seeing how children respond to each other's treatment of him. The initial case study that I did at TK ABA Aisyiyyah 20 by following the activities of one student with a single parent background (single parents), there are several things that distinguish the child from other children specifically. If the general attention, the child has no difference with other children where the child can still follow the instructions directed by the teacher such as: putting shoes in place, kissing the teacher's hand when meeting, and greeting when entering class. However, it turns out specifically that children with a single parent's background tend to prefer to cry when unable to complete the task given by their teacher. When learning as a group children also tend to be passive and do not have the motivation to participate in learning together. In addition, children also prefer to disturb the concentration of their friends while studying. This is often done by the child while in school. Judging from the many negative aspects of the child with a single parent, the writer analyzes the achievements of children with single parents on their emotional social.

\section{THEORETICAL}

According to Habibi [5] early childhood is children who are aged 0-8 years and 0-6 years). An early child is an individual who is at an early age and still needs guidance and education from an older person to develop various potentials that are owned during their growth and development. According to [6] an early age child is a child whose age has not yet entered a formal education institution such as elementary school (SD) and usually they remain at home or participate in activities in the form of various pre-school educational institutions. Rabiah and Tamba the age of 5-6 years is the best period for children to learn to develop the ability to socialize and express emotions positively. The ability of socialization and children's emotions is greatly influenced by the environment and guidance from parents to introduce and provide understanding to children about the norms and rules that exist in social life.

Bredekamp \& Copple [7] stated that the characteristics of early childhood development need to be understood by educators to facilitate the assistance in early childhood development as students, among others; (a) The realm of children's physical, social, emotional, linguistic and cognitive development are interrelated, that is, developments in one domain affect and are influenced by developments in another domain; (b) Development takes place in a relatively orderly manner with subsequent abilities, skills and knowledge built on capabilities, skills and knowledge that have been previously achieved; (c) Development takes place at different speeds from one child to another; (d) Initial experience has a cumulative effect and the effect of delay on individual child development, in the optimal period occurring in certain types of development and learning; (e) Development takes place based on predictable directions towards complexity; (f) Development and learning within and influenced by various social and cultural contexts; (g) Children are active learners, they take direct physical and social experience and knowledge that is spread through culture to shape their understanding of the world around them; (h) Development and learning originate from the interaction of biological maturity and the environment which includes the physical and social world in which children live; (i) Play is an important tool for children's social, emotional, cognitive, and language development as well as a reflection of their development; (j) Development advances when children have the opportunity to practice the newly acquired skills as well as when they experience challenges above their current level of mastery; (k) Children show different ways of knowing and learning as well as different ways of realizing their knowledge; (k) Children develop and learn very well in the context of a community where they feel safe and valuable, their physical needs are met, and they feel psychologically safe.

As for other opinions [8] the characteristics of kindergarten age development are as follows; (a) Physical and motor development, there are very different characteristics when a child reaches kindergarten age (3-6) years with the baby's age such as: appearance, body proportion, body weight, and the skills they have; (b) Cognitive development, according to Piaget divides the stages of cognitive development in four stages, namely: sensory motors age 0-2 years, preoperational ages 2-7 years, concrete operational ages 7-14 years, formal operational age of 14 years, kindergarten age children are at the preoperational stage which is the stage where the child has not, logically mastered mental operations. This period was marked by the development of the ability to use something to represent something else by using symbols; (c) Emotional development, emotional development is related to all aspects of child development in which early childhood emotions are more detailed or differentiated and tend to express their emotions freely and openly; (d) Social development, social development is the development of the child's behavior in adjusting to the rules of the community where the child is located, this development is obtained by the child through maturity and learning opportunities from various responses to him; (e) Language development, early childhood usually has been able to develop speaking skills through conversation such as asking questions, dialoguing and singing, where in the first years of life known as pralinguistic stages which are then followed by linguistic stages become the main communication way.

According [9] the family is the smallest unit in society, consisting of men and women united through marriage ties. Both of them have a commitment to decide to live together in a bond that is prepared together. The smallest unit will produce a family consisting of father, mother and child. That is a simple picture in general that occurs in society. According 
to Ridwan Syahrani the family is a social unit consisting of husband, wife, and children who are immature is a place of intensive socialization and transformation of moral values, ethics, and social. In the family there will be a rule, ethics and social morals in the community. So that each family member can be accepted and adapt or socialize to others in accordance with the rules and norms that exist in society. According families are divided into several types namely; (a) nuclear family / nuclear family consisting of a husband and wife together with unmarried children; (b) extended family (extended family) consisting of a family of batih and children who live in a separate house but still in the same land; (c) grabineal family (maxime ramage) where the members consist of a broad family of 25-30 people from three or four generations who are still one ancestor, live in the same place and jointly control productive assets and the results can be enjoyed together.

In general, a single parent is a family that only has one person consisting of a mother or father who lives with children after a divorce, death or childbirth outside of marriage. According to Syamsu [10] single parent families, i.e. families whose parents only consist of mothers or fathers who are responsible for taking care of children after divorce, death or child birth out of wedlock. The family has a very important role in efforts to develop a child's personality. The loving care of parents and education about the values of life, both religious and socio-cultural that they provide are conducive factors for preparing children to become personal and healthy members of society. Alisyahbana [11] stated in Indonesian society that the role of a father is very large, the father is the economic source of the mother's family gathering or arranging daily food for her husband and children. Because of the large role of fathers in the family economy, the position is also very large and decisive in family decisions. Once the importance in the family of mothers and fathers in carrying out their respective roles. So there is no imbalance in family life. According single mother, understanding Single Mother is a mother as a single parent must replace the role of the father as head of the family, decision makers, breadwinners in addition to his role in taking care of the household, raising, guiding and fulfilling the child's psychological needs. Making mothers as housekeepers and as breadwinners. A single mother will make mothers have a dual task of caring for, educating and raising children. This is what makes mothers have multiple functions and obligations. Meanwhile, according to Yeni single parents choose to work, obviously requiring time, energy and full concentration, which results in a reduced home presence. Especially time to take care of their children, so that their children do not get optimal care from their parents. According to Woolfolk [12] states that two years after divorce seems to be the most difficult period for boys and girls. During this period, children may experience various problems at school or not at school, lose or gain weight, experience sleep problems or experience other difficulties. Problems that occur in children the impact of a conflict in the family. Therefore the importance of a whole family in creating a comfortable and conducive atmosphere for the development and growth of children optimally.

According to Tania [13] the responsibilities and tensions faced by single parents are certainly heavier than those faced by parents who are whole or complete when raising children. Single parents have less time and often have less financial resources. Some single parents, such as widows and widowers or adoptive parents, experience special tension. Widowed parents or widowers experience great sadness and life changes that can limit their ability to deal with a child's attitude. According to Tania the responsibilities and tensions faced by single parents are certainly heavier than those faced by parents who are whole or complete when raising children. Single parents have less time and often have less financial resources. Some single parents, such as widows and widowers or adoptive parents, experience special tension. Widowed parents or widowers experience great sadness and life changes that can limit their ability to deal with a child's attitude. According to Haninah [14] the roles and responsibilities of both mother and father as a single parent will increase, she must earn her own living, make important decisions herself, and so many tasks or responsibilities must be carried out as single parents ). Major changes that must be carried out as a mother as well as a father, on the contrary a father who must carry out his role as a father as well as a mother. A single parent, even without the help of their partners, still performs their role well as the backbone of the family and also as a role model for their children. Based on the explanation above, the responsibility of a single parent in addition to having to work for a living for their family must also educate children and play a dual role as a father and mother for their children.

According to Asyhari single parent is a woman or man who is a parent who is also a father and mother or vice versa in raising and educating children, and regulating family life due to changes in family structure either due to the death of a spouse due to divorce or death. According to Hanifah [15] single parents can be caused by several factors such as divorce due to incompatibility or due to economic factors, death due to accidents or due to continuous illness, because one of a spouse is a drug addict and a convict so that his responsibilities in the family cannot be expected, pregnancy out of wedlock, for a woman or man who does not want to get married then adopts someone else's child. Based on the above opinion it can be said that the factors causing being a single parent are caused by several things such as divorce, death, continuous illness experienced by one of the partners, then because one of a couple is a drug addict and convict, an unmarried pregnancy and a desire not to get married and decide to adopt a child. Development (development) is the increase in the ability (skill) in the structure and function that is more complex in an orderly and predictable pattern, as a result of the maturation process. In this case the development is an increase in the ability of each individual who experiences a systematic development. Meanwhile, according to Desmita [16] defines development is not limited to the understanding of physical changes, but also contains a series of continuous changes in the physical and spiritual functions of the individual to the 
stage of maturity, through growth and learning. According to Soetjiningsih [17] states the development (development) is the increased ability in the structure and function of the body that is more complex in an orderly and predictable pattern, as a result of the maturation process. The connection with this is related to the process of differentiation of body cells, body tissues, organs and organ systems that develop in such a way that each can fulfill its function. Including the development of emotions, intellectuals and behavior as a result of interaction with the environment.

According to Yudrik factors that influence child development are factors that can be changed / modified, namely heredity, and factors that cannot be changed or modified, namely environmental factors. Some factors that affect a child's growth and development are as follows; (a) hereditary / hereditary factors; (b) sex; (c) race; (d) the socioeconomic status of the family; (e) nutrition; (f) deviations in health conditions; ( $g$ ) sports; (h) sequence of children in the family and intelligence. Some of these factors are very important things that affect children's growth. The importance of development in early childhood is a family task in stimulating or stimulating the development that will be experienced by every child. Suyadi [18] divides the pattern of social emotional development of children 0-6 years into 9 aspects, namely, fear, shame, worry, anxiety, anger, jealousy, grief, curiosity and pleasure as shown in Table 2.3.

\begin{tabular}{|c|c|c|c|}
\hline No & Parenting & Stimulation & Response \\
\hline 1 & Afraid & $\begin{array}{l}\text { Loud Noise, Dark, } \\
\text { Animal, and Bad Feel. }\end{array}$ & $\begin{array}{l}\text { Limp helpless, crying, } \\
\text { and screaming for help. }\end{array}$ \\
\hline 2 & Shy & Unknown person. & Cry and look away \\
\hline 3 & Worried & $\begin{array}{l}\text { Exaggerating } \\
\text { shortcomings } \\
\text { imagine it }\end{array}$ & haunted face worried \\
\hline 4 & Anxiety & $\begin{array}{l}\text { Pessimistic } \\
\text { cornered. }\end{array}$ & $\begin{array}{l}\text { Depressed, nervous, and } \\
\text { easily offended }\end{array}$ \\
\hline 5 & Angry & $\begin{array}{l}\text { Obstacles } \\
\text { motionrestrictions }\end{array}$ & $\begin{array}{l}\text { Shut up, speak harshly, } \\
\text { and act anarchist }\end{array}$ \\
\hline 6 & Jealousy & Lake of attention & Unsafe and doubtful \\
\hline 7 & Sorrow & $\begin{array}{l}\text { Missing something } \\
\text { loved }\end{array}$ & Cry \& Unsleeping \\
\hline 8 & Coriosity & New everything. & Frown and open mouth. \\
\hline 9 & Happines & $\begin{array}{l}\text { Good physique, } \\
\text { player, and something } \\
\text { different }\end{array}$ & $\begin{array}{l}\text { Laugh, crawling, walk } \\
\text { and run }\end{array}$ \\
\hline
\end{tabular}

Hurlock (in Hasnida, 2014: 34) social development means the acquisition of the ability to behave in accordance with social demands and requires three processes namely; (1) Learning to behave socially acceptable; (2) Playing an acceptable social role; (3) Development of social attitudes. From an early age children are introduced and taught to behave and behave in accordance with the norms and ethics that apply in the community where he lives in accordance with the age of the child. According to Sofyan [19] social development is obtaining the ability to behave in accordance with social demands and be able to socialize by requiring the following three processes properly, children must like people and social activities, if they succeed in doing so they will be able to adjust to good and will be accepted as a member of the group.

\section{RESEARCH OF METHOD}

The subjects of this study were early childhood, school principals, parent teachers in 3 kindergarten and PAUD schools, namely PAUD Al-Bahri as Respondent I, TK ArRidho Medan as Respondent II and TK ABA Aisyiyyah as Respondent III AS WELL and the Women's Empowerment and Protection Office Province of North Sumatra Province. For the object of research is the social emotional development of children from 3 schools that are raised by a single parent. In this study the object of research focuses on the social emotional achievement of early childhood and social behavior of early childhood who are cared for by a single parent, father or mother. The research method used in this research is descriptive analytical qualitative method. Data collection techniques in this qualitative study: observation, interviews, documentation and questionnaires. In this study data analysis was carried out in 3 stages namely; (a) Data reduction (b) Presentation of data (c) Drawing conclusions.

\section{RESULT AND DISCUSSION}

From the results of the analysis in this study, the authors found several things related to social emotional development in children with single parents.

\section{A. Children who are raised by a single parents (mother) tend to be more quiet than other children.}

From interviews that I did with parents and teachers, the authors found 3 child informants who were cared for by a single parent, the mother. Children with parenting foster parents (mothers) tend to have a quiet attitude because: (a) often ignored, children who are often ignored will be quiet children. Parents who are too busy or do not care about the presence of their children will be the cause of the quiet child. Children who are rarely spoken to, will gradually become quiet children. Parents should respond to children when they speak; (b) often scolded, parents who often scold children often say the words "silent" when their children try to respond to their parents' anger. Unwittingly, this turned out to be true. Children who are often scolded and ordered to be silent become quiet children [20]. Children who are often scolded also experience pressure on their self-confidence. He felt often wrong so he chose silence rather than being scolded. A good parent will correct this and change his attitude to be more gentle. Faster improvement is a better solution; (c) rarely given a positive response when communicating or asking about something, often parents do not consider the importance of a positive response. Positive responses that can be given in the form of praise, hugs, kisses, gifts and others. There are children who are initially open and want to show the ability or good attitude to their parents. However, parents only see or say things that are not good [21]. Parents should give praise and hug and kiss the child when the child tells the work or good attitude. If parents only give a cold response then the child will feel in vain to do something and show his parents. As a result, children choose to be quiet. 


\section{B. Permissive (tend to behave freely)}

Permissive (tend to behave liberally) is one of the communication patterns in which parents do not care about what will happen or what has happened to their children, parents tend not to respond or not respond if the child talks or express the problem. Things that happen on the field, for example, when children make a mistake in school, parents will not respond and do not respond to their children. In many cases children are too given the freedom to make decisions. So the child does not feel cared about by his parents, even when the child makes a mistake that he has done or things that should not happen can be repeated many times [22]. Then the child will feel that there are still many who are lacking or the child still feels he is unable, so the child will lose confidence, not only that the child will have a dominating nature, unclear direction of life, low achievement, and sometimes the child is not respect other people, always selfish, and do not have empathy with others. Things that happen on the field, for example, children feel less attention because their parents are busy looking for money and he becomes unclear life. Based on observations that the author has done there are 5 informants who apply permissive and are dominated by a single parent, namely Father.

\section{Behavior Change}

Children with complete parenting parents have a stable attitude. that is, the child can balance emotions with friends or like sharing toys, apologizing when doing wrong, greeting when meeting the teacher. However, under certain conditions this change can occur for a child who is not ready to be abandoned by his parents, which can result in a change in behavior. Being angry, saying rude, like daydreaming, aggressive, likes to hit, kick, hurt his friend. Also do not have the opportunity to learn good behavior as a harmonious family behavior. The most dangerous impact when a child seeks escape outside the home, such as being a street child, is affected by the use of drugs to eliminate all anxiety in his heart, especially children who are less affectionate and lack parental attention. From the research conducted by children who have abusive behavior from 3 schools studied there are 2 children with these behaviors. 1 child with parenting single parent (father) parenting due to mother who died and 1 other student with parenting single parent (mother) parenting divorce.

\section{CONCLUSION}

The process of adaptation of children after divorce between their parents is closely related to the attitude of the mother or father to divorce. Where the child's behavior tends to follow the pattern of parenting mother and father. In addition, the openness of a single parent father or mother makes children more able to understand the burden borne by the mother. The process of communication that the mother or father does in providing an understanding of the child about the mistakes that are sometimes made by the child forms an attitude of self-introspection (self critism) in the child. The role of the mother or father himself as a single parent has a big role in maintaining relationships with children after the divorce. This pattern of care in a single parent family creates responsibility as a form of dedication. And the values applied in parenting communication result in a close relationship between a single mother or father and a child in which there is a sense of trust, supportiveness and openness between one another.

\section{References}

[1] Rabiah dan Wayan Tamba. 2014. PengaruhBermain Peran Terhadap Kemampuan Sosial Emosional. Jogjakarta: Ar-Ruzz Media.

[2] Achmad, IF., Latifah, L., Husadayanti, DN. 2010. Hubungan Tipe Pola Asuh Ołrangtua Dengan Emotionalquotient (EQ) Pada Anak Usia Prasekolah (3-5 TAHUN) Di TK Islam Al-Fattah Sumampir Purwokerto Utara. Jurnal Keperawatan Soedirman. Vol. 5 (1) : 47-57

[3] Sari, A. 2015. Model Komunikasi Keluarga Pada Orangtua Tunggal (Single Parent) dalam Pengasuhan Anak Balita. Jurnal Ilmu Komunikasi. Vol 3 (2) : 126-145.

[4] Ahsyari, Era, R. 2015. Kelelahan Emosional dan Strategi Coping Pada Wanita Single Parent (Studi kasus: Kab. Paser). Ejournal Psikologi Unmul, 3(1): 422-432.

[5] Habibi, Muazar. 2018. Analisis Kebutuhan Anak Usia Dini. Yogyakarta: Deepublish.

[6] Nurmalitasari, Femi. 2015. Perkembangan Sosial Emosi pada Anak Usia Prasekolah. Buletin Psikologi. 23 (2): 103-111.

[7] Ramli. 2005. Pendampingan perkembangan Anak Usia Dini. Jakarta: Departemen Pendidikan Nasional Direktorat Jenderal Pendidikan Tinggi Direktorat Pembinaan pendidikan Tenaga Kependidikan dan Ketenagaan Perguruan Tinggi.

[8] Masito, dkk. 2005. Pendekatan Belajar Aktif di Taman Kanak-Kanak. Jakarta: Departemen Pendidikan Nasional Direktorat Jenderal Pendidikan Tinggi Direktorat Pembinaan Pendidikan Tenaga Kependidikan dan Ketenagaan Perguruan Tinggi.

[9] Rahman, Hermia Ananta. 2014. Pola Pengasuhan Anak yang Dilakukan Oleh Slingle Mother Kajian Fenomenologi tentang Pola Pengasuhan Anak yang Dilakukan oleh Single Mother di Kelurahan Sukoharjo, Kecamatan Sukoharjo, Kabupaten Sukoharjo. Jurnal Sosiologi Antropologi. 13 (6) : 2-11.

[10] Woolfolk, Anita. 2009. Educational Psychology: Active Learning Edition. Yogyakarta: Pustaka Pelajar.

[11] Alisjahbana, A. Shidarta, M, Brouwer,M.A.W. 1983. Мепији Kesejahteraan Jiwa. Jakarta: Gramedia.

[12] Yudrik, Jahja. 2011. Psikologi Perkembangan. Jakarta. Kencana.

[13] Putri, AS. 2016. Pola Komunikasi Single Parent dalam Mendidik Anak (Studi Kasus di Desa Banglas Barat, Kecamatan Tebing Tinggi, Kabupaten Kepulauan Meranti). Jurnal Jom Fisip. 3 (1) : 1-18.

[14] Haninah. 2015. Peran Ibu Sebagai Orang Tua Tunggal (Single Parent) dalam Menanamkan Pendidikan Agama Terhadap Anak di Lingkungan Keluarga. Jurnalfis Untan. 3 (I) : 84-91.

[15] Hanifah, Mutia. 2015. Perancangan Kampanye Sosial Bahasa Isyarat Tunarungu Melalui Media Video Infografiis. Bandung: Universitas Komputer Indonesia.

[16] Desmita. 2005. Psikologi Perkembangan.Jakarta: Pt Remaja Rosdakarya.

[17] Donna L. Wong. ...... et all. 2008. Buku Ajar Keperawatan Pedriatik. Cetakan pertama. Jakarta : EGC.

[18] Suyadi. (2010). Psikologi Belajar Anak Usia Dini. Yogyakarta : PEDAGOGIA.

[19] Sofyan, H. 2014. Perkembangan Anak Usia Dini dan Cara Praktis Peningkatannya. Jakarta: CV. Infomedika.

[20] Astuti, D. 2016. Keterlibatan Pengasuhan Ayah Sebagai Orang Tua Tunggal dengan Anak Perempuannya Setelah Terjadinya Perceraian (Studi Kasus Komunikasi Antarpribadi Di Desa Kwangsan Kecamatan Jumapolo). Jurnal Komuniti. 3 (1) : 19-34. 
[21] Hasnida. 2014. Analisis Kebutuhan Anak Usia Dini. Jakarta : PT. Luxima Metro Media.
[22] Syamsu, Y. 2001. Psikologi Perkembangan Anak dan Remaja. Bandung: Remaja Rosdakarya. 